\title{
The Traditional Arts and Cultural Policy in Banyuwangi
}

\author{
Novi Anoegrajekti' ${ }^{1}$, Sudartomo Macaryus ${ }^{2}$, Ali Imron Al-Ma'ruf ${ }^{3}$, Siti Gomo Attas ${ }^{4}$, \\ Agustina Dewi Setyari ${ }^{5}$, Zahratul Umniyyah ${ }^{6}$ \\ \{novianoegrajekti.sastra@unej.ac.id ${ }^{1}$,sudartomo@ustjogja.ac.id ${ }^{2}$,aliimron_almakruf@yahoo.c \\ om ${ }^{3}$,tigo_attas@yahoo.co.id ${ }^{4}$, agustina.sastra@unej.ac.id ${ }^{5}$, zahraniya333@gmail.com ${ }^{6}$ \} \\ 1,5.6 Universitas Jember, Indonesia \\ ${ }^{2}$ Universitas Sarjanawiyata Tamansiswa, Yogyakarta, Indonesia \\ ${ }^{3}$ Universitas Muhammadiyah, Surakarta, Indonesia \\ ${ }^{4}$ Universitas Negeri Jakarta, Indonesia
}

\begin{abstract}
Gandrung Traditional Art in Banyuwangi is placed as a cultural event. Nowadays, it is decreasing, because it is only a place for the State (bureaucracy), religion and markets to fight. For this reason, it is necessary to revitalize traditional arts through increasing the innovation of traditional arts based on locality. This paper discusses how the revitalization and dynamics of the Gandrung tradition of art in the midst of socio-cultural changes in Banyuwangi. Analysis with cultural studies approaches, this paper produces an in-depth description and understanding of various social and cultural forces in relation to the traditional arts of Gandrung in Banyuwangi. The model of locality-based innovation as a cultural policy produced is expected to support the development of Gandrung traditional art in Banyuwangi. Socialization, promotion, and marketing as well as utilizing cultural activities that take place in Banyuwangi, are packaged in the Banyuwangi Festival Calendar as a form of revitalizing traditional arts.
\end{abstract}

Keywords: Beach Ball Investigation Group, Social Skill, Cooperative Learning, Model, Development, Speaking.

\section{INTRODUCTION}

Speaking course Gandrung's art tradition rests and survives on the basis of the local values that it contains dealing with new demands that not only ensure modern rationality and propriety, but also involve survival in economic terms. This will determine whether the art is likely to live or not in the future. A long history of Gandrung leaves a note that the art of the Using community is always faced with forces outside of itself. Market, bureaucracy and religion have long been the forces that squeeze the art of this tradition. The contact of traditional art with the three agents of strength reaches the peak of its intensity.

Markets, traditions, and religions have functioned as forces that favoured interests and carried their social and cultural authority through traditional arts. Instead, the three also show battles in space with different positions and categories or in Williams's terms [1] in an 
incorporation with position as dominant culture, residual culture, and emergent culture. The longest and most intensively touching market for traditional art has become dominant, the bureaucracy and the Blambangan Arts Council which seek to restore the traditional art of Gandrung as in the past can be categorized as residuals, and Islam which in the context of favour is something new becoming emergent.

Market domination over traditional and Islamic art can be seen in every Gandrung show which is entirely more market-patterned. Gandrung art is very likely to present some things as tradition conservation and singing songs such as Shalatun wa Taslimun at the same time or one of the two, however, at the same time the show is an open, commercial, and full of aroma of alcohol. Every Gandrung show has slices of the three powers above, even though the market is the biggest and dominant slice.

In the incorporation the relationship between the power of hegemony is alternative but it also can be opposition which then causes relations and positions of power to be unstable, dynamic and changing. Instability is maintained other than because hegemony itself as a cultural process that links (construction and reinterpretation) of the past and (fantasy) of the future, also because the market contested, tradition conservation, and Islam are representations of identity, something within which various possibilities are possible mean.

In the religious leaders' views, Using society must be consistent with religious teachings that prohibit civil behavior and stay away from immorality. Art tradition, including women's traditional arts must be in accordance with Islamic teachings. The adjustment makes the Gandrung show not serving erotic dance and pairing, not opening aurat, and providing liquor.

In contrast, the bureaucracy and the Blambangan Arts Council see that Using is an ethnic community that is separate from Java (having its own language and customs), installed in terms of stereotypes and stigma, excluded from political and economic circles, and has proud historical experience. Based on such identification, the strength of this hegemony is to formulate, that "the Gandrung show is nothing but a picture of the resistance of a society (Using). Resistance to various threats, which are physical and negative imagery that occur repeatedly in the history of Using society."

Government policy in the preservation and development of local culture, turned into a manager to fit the demands of developmentalism, namely increasing regional income. In this situation, art is seen as an object and is expected to adjust to the demands of consumerist development. Current policies have changed and damaged the culture and art of tradition through excessive interference and policies that lead to commodification [2]; [3]; [4]; [5]; [6] .

So far, traditional arts have only become a battleground for power to show artificially the power of the state (bureaucracy), religion, and markets, as well as the representation of identity of group interests, including cultural communities. Thus, regional cultural policies are refracted for economic interests and local political power which actually erodes the preservation of the traditional arts itself [7]. This will become the novelty in this paper.

\section{METHOD}

Gandrung performance is the object being studied. By placing the show as a marker, it has theoretical consequences to associate the relationship between the marker (signifier) and signified. The construction and choice of markers are then manifested in representations, an "image or restatement of reality in a visual and verbal form that implies certain meanings and ideologies. Representations can be considered as 'battlefield' interests or power [ 8].' Visual and verbal forms mean that representation has certain materialities that can be read or seen and that materiality is produced, displayed, used, and understood in certain social contexts. As 
something that starts from construction and meaning, representation that is always related to that identity is not possible to be understood as something natural and given, precisely because of the uncertainty in the representation itself.

As is usual in an ethnographic analysis, the interpretation method is used to access deeper into the various domains experienced and the activity characteristics of the cultural actors studied [9]; [10]. As something that is built up, identity is something discursive, cracked, and changes with changes in space-time. It needs to be realized by the Using Banyuwangi community that the battles and conflicts that arise can be understood proportionally, as sociocultural struggles in the dynamics of life and life can provide encouragement and encouragement to develop negotiation capabilities towards cultural politics in the future. Therefore, the recording and meaning of each historical cultural policy needs to be carried out as a step of understanding and determining further policies that are increasingly functional, involve, prosper, and empower the supporting community.

\section{RESULT AND DISCUSSION}

\subsection{Gandrung Traditional Arts}

This Research and Development design answered two research questions. Gandrung Banyuwangi comes from the word gandrung, which means 'crazy or out of love'. This dance is still one genre with dances such as Ketuk Tilu in West Java, Tayub in Central Java and western East Java, Lengger in Cilacap and Banyumas and Joged Bumbung in Bali, which involves a female professional dancer who dances with guests (especially men) with musical or gamelan accompaniment.

This dance is popular in the Banyuwangi region which is located on the eastern tip of Java Island, and has become a characteristic of the region, so it is not wrong if Banyuwangi is always identified with Gandrung, and you will find Gandrung dancer statues in various corners of the Banyuwangi region, and no doubt Banyuwangi is often nicknamed Gandrung City. This Gandrung dance is often performed at various events, such as marriages, pethik laut ceremony, circumcisions, seventeenth birthdays and other official and informal events both in Banyuwangi and other regions.

The gandrung show starts at 21.00 and ends around 3:30 in the morning, divided into three parts: Jejer, Paju, and Seblang-seblang. Jejer (opening) lasts about 45-60 minutes (Jejer) and Seblang-seblang (closing) about 85-120 minutes. Paju scene lasts for 4-5 hours and open to audiences to dance in pairs or sing songs. In the scene Jejer, Podho Nonton song was sung. The poem describes the struggle to arouse and arouse the people of Blambangan to overcome all forms of colonialism. The message of the struggle is symbolically revealed and only understood by some people of Banyuwangi. Padha Nonton is a historical notch that needs to be remembered and lived by the Using community. Sutomo, a promoter stated that for the Gandrung community, kidulan, Jejer dan Seblang-seblang is a formality that does not have to be presented.

The Gandrung show is simple. As a dance and singing-based art, Gandrung performances are very loose and involve the audience. With accompaniment of sinden voices or without sinden, Gandrung dancers waddle on the ground alone, along with other Gandrung, or together with the promoters. Panjak lined up to form a crescent moon in the middle as a stage background, playing a musical instrument each with the most prominent drum and kluncing. Musical instruments in the form of: drums (lanang and wadon), tap or kenong, violins which in local terms are called baola. They are in uniform: koko cloth made of silk in light blue, pink or light yellow, trousers with a sarong tied around the waist, and head tie. 
Padha Nonton is a description of the history of Using people who were colonized and resisted to always be watched by the Blambangan generation. The Paju scene gives the audience the chance to dance in pairs. On this occasion, the promoters demonstrated their abilities in dance or pencak silat arts. The songs that were sung were among others: Cengkir Gading, Condro Dewi, Celeng Mogok, Ukir Kawin, Erang-erang, Sukma Ilang, es Lilin, Cap Go Mek, Kusir-kusir, and Lia-liu. At present, the audience sometimes asks for new songs that are popular in the community.

During ngrepen, the gandrung dancer sits at the table of the promoter in turn according to the serial number arranged by the handyman gedhog who regulates traffic of paju. At each table, dancers sit together with the pemaju (promoter). Dancers also act as singers if the show without using sinden. After completing 2-3 songs and dancing in pairs with pemaju, the dancers then moved to the next table. The numbers of pemaju and kalangan ranging from 70 to 100 people at one night's show. The popularity of dancers shown is indeed very influential on the number of pemaju and the kalangan who present.

Seblang-seblang as the closing all the performances took place before dawn. Therefore, Seblang-seblang is also known as Seblang subuh. The word seblang means 'Be aware 'back to time. Songs sung in Seblang-seblang intended to: apologize to those who hold the title, express their gratitude to the guests, and call back to the real-life atmosphere. Banyuwangi artists agree that the lyrics and patterns of dance in Seblang-seblang was adopted by the Seblang ritual, the village clean ceremony at Olehsari and Bakungan. Seblang-seblang seems to be very religious. Gandrung dancers invite guests not to lose control and recommend immediately returning to their homes to gather with their families.

\subsection{Cultural Policy}

Some cultural policies that favoured the artists and the community appeared in the Gandrung training, the performance of the Gandrung Sewu and Gandrung Paju Festival, the participation of the Janger Group in various traditional theatre festivals, and the expansion of the Kuntulan performance arena. ${ }^{1}$ Some of these policies and other policies need to be carefully examined in relation to life and the development of traditional arts. Regarding traditional arts, it becomes part of cultural policies. However, it is also possible for policies in the field of traditional arts to support cultural policies in a wider scope.

Regent Djoko Supaat Slamet's policy in the field of developing traditional arts was seen in his efforts to enable Lekra artists to continue working, with restrictions not to include Communist propaganda. In this way the artists who are members of the Lekra, namely Andang CY, Slamet, and Endro Wilis can continue to work and be accepted in the Banyuwangi community.

Determining the location of Using tourist village in Banyuwangi District Level II shows the government's attention in the field of tourism, especially cultural tourism. The choice falls on the Kemiren Village which is indeed one of the concentrations of the Using community. This decision gives space for the expression of the culture of the people to be presented in tour packages. In Kemiren there are several traditional arts groups, such as gandrung, barong, kuntulan, and angklung and some traditions that are still lived by the community, such as mocoan, tumpeng sewu, mepe kasur, and barong ider bumi. All of that becomes the carrying capacity of Using tourism villages. On the contrary, the establishment of Kemiren as a tourist

1. In 2013, Kuntulan was included in the Indonesian Independence Day commemoration ceremony which was performed together with the demonstration of the skills of TNI members. 
village Using is also a supportive force that is still alive and the development of various traditional arts and rituals in the Kemiren Village. This policy was taken during the reign of Regent T. Purnomo Sidik.

Another policy is seen in the designation of gandrung as a Banyuwangi tourism mascot in 2001 (Banyuwangi Regent Decree Number 173 2002), followed by the next policy in the form of the formation of the dancer Gandrung dance as a welcome dance in Banyuwangi Regency in 2003 (Banyuwangi Regent Decree Number 147 2003), and the designation of "Umbulumbul" Belambangan's song as a song of encouragement to build Banyuwangi in 2003 (Banyuwangi Regent Decree Number 148 2003). These three policies were established during the reign of Regent H. Samsul Hadi. This policy provides space for the expression of traditional art actors.

The next policy, during the reign of Regent Ratna Ani Lestari was the rambling Banyuwangi movement which focused on creating a clean, cool, beautiful, beautiful and comfortable natural environment. This is also needed to support the development of tourism in Banyuwangi. The movement was followed up by Regent Abdullah Azwar Anas with the regent regulation of Banyuwangi on guidelines for implementing the green and clean Banyuwangi movement in Banyuwangi Regency (Banyuwangi Regent Decree Number 34 2011). Clean culture and the natural environment as mentioned above are useful for supporting tourism.

This phenomenon shows that government policies are complementary and sustainable. Therefore, some advanced policies in the field of culture can be said to be an accumulation of policies taken by previous regents. This is in line with the views of one of the community leaders (Purwadi) in an informal conversation with the author. In his view, big events like BEC, Gandrung Sewu, Ijen Summer Jazz Festival, what happened during the reign of Regent Abdullah Azwar Anas was supposed to happen at this time. He is reaping the fruits of the seeds planted by his predecessors.

\subsection{Policy Accumulation}

The reign of Regent Abdullah Azwar Anas in the first period of 2010-2015 and the period of 2016-2020 was an accumulation of policies which culminated in major activities as a means of promotion and introducing Banyuwangi's tourism and cultural potential. The policy direction appears in the Banyuwangi Regent's Accountability Report at the end of his tenure in the period 2010-2015 which states that the cultural goal is to increase the preservation and development of local culture. The strategy used is to preserve and develop local culture. The policy directions taken are: (1) growing community interest in local culture, (2) strengthening local culture groups and communities, (3) providing training, local cultural and artistic festivals, (4) establishing local curricula (culture, art) in education, and (5) development of a space for appreciation of local culture [11]; [12] .

The macro policy targets are outlined in detail and comprehensively in five policy directions. It is said to be comprehensive because it is aimed at three regions, namely: (1) society as cultural actors, (2) cultural preservation community, (3) space for cultural art expression, and (4) cultural arts education. People as cultural actors need attention because community support is one guarantee of the survival of the culture they live together. Besides that, genetically people will continue to grow to live in line with the dynamics of their civilization. Cultural conservation communities generally pay attention and interest in certain cultural fields, such as traditional arts, rituals, clothing, culinary, and traditional technology. These communities generally live independently. But in the midst of the development of pop culture they need protection and advocacy in order to survive. Such protection and advocacy 
can be in the form of management training, traditional technology transfer to modern, product design, and business diversification. The enthusiasm to protect was stated in the speech of the Regent of Banyuwangi at the opening of the 2013 Banyuwangi Regency development plan deliberation, as follows:

"On various occasions I convey, if we have not been able to improve people's welfare, we must reduce the burden of expenditure. Coconut collectors, sweepers, parking attendants must be protected. Likewise, traditional small traders must get protection, because as much as any capital, as long as people are not protected, they will lose (2013: 11). (Regent of Banyuwangi. 2013. "Principal Message from the Banyuwangi Regent at the 2013 Musrenbang Opening Ceremony of the Banyuwangi Regency." Banyuwangi").

Even though it is not explicitly mentioned, the traditional arts practitioners who have made Banyuwangi famous for their economic difficulties are certainly those who need attention and have improved welfare. Gandrung Temu is still receiving attention and stage opportunities and awards, even currently establishing the "Sopo Ngiro" studio in Kemiren. In August 2015, I got the chance to perform in Frankfurt Germany. Gandrung Temu, because of her loyalty to the art of tradition and maintaining a standard convention, is still the mecca of young and cheerful dancers. Awards, responses, and the attention of the public, scientists, government agencies, and the private sector are still quite large. The intention of establishing and completing studio facilities received support from scientists who made them respondents from their research and studies on the traditional art of Gandrung [3]; [14] .

This situation is different from that experienced by Gandrung Poniti and Kusniah who received awards from the Banyuwangi Regency Government at the Gandrung Sewu event (September 26, 2015) as a form of attention and recognition by the government towards the preservation figures of traditional arts in Banyuwangi. Poniti was famous as a belle of prominence in 1968 to the 1980s. Currently she lives in Tegalmojo, Gambiran District, Banyuwangi Regency. Poniti occupies a very modest house with a poor economic situation. The rest of her life she lived by working on two remaining fields of rice fields while waiting for an offer as a sinden gandrung, kuntulan, jaranan, or janger [15]. Therefore, the award from the government is a form of recognition, respect, and attention to the perpetrators of traditional arts who have helped to make Banyuwangi famous. Whereas the government's recognition that it has not been able to bring prosperity to the entire community including the Poniti and Kusniah gandrung shows the attention and humility of the government who wish to prosper the people.

\section{CONCLUSION}

The Cultural policies outlined in the form of legal products in the form of Perda, Regent's Decree, and Regents Regulations which mention traditional arts since the 1995 period until now are only Regent Decrees, namely Kemiren Tourism Village, Gandrung as Banyuwangi tourism mascot, and Jejer Gandrung Dance as dance for welcoming guests in Banyuwangi. Other cultural policies are general and macro in nature which are then responded and translated by each SKPD according to their respective duties. The Office of Culture and Tourism promotes, the Department of Industry and Trade disseminates to youth organizations to be followed up with trainings.

The systemic approach taken by Regent Abdullah Azwar Anas by compiling cultural events in the Banyuwangi Festival Agenda and publishing them online and using banners and billboards, proved effective especially in attracting guests to attend and witness the cultural event. This method proved to be effective in increasing the number of visitors 
significantly. The big event in the field of art and culture that is currently taking place by many people is seen as an accumulation of the previous policy stages. Inter-regent policies should be continuous and sustainable. The difference between regents is not on purpose, but on strategies for achieving and realizing the policies and programs that have been designed.

One policy in the form of a legal product or in the form of a work program is proven to have multiple impacts. The policy on Using Tourism Village moves and influences the development of various traditional arts that take place in the village environment. Therefore, in determining the program and design of legal products it is necessary to estimate and consider the possible consequences or risks of certain policies. The activity also had an impact on community empowerment, increasing welfare, and community independence.

\section{REFERENCES}

[1] Williams, Raymond. Marxism and Literature. Oxford University Press, 1977.

[2] Howkins, John. The Creative Economy: How People Make Money From Ideas. Penguin Press, 2002.

[3] Shan, Shi lian. "Chinese Cultural Policy and the Cultural Industries." City, Culture and Society, vol. 5, no. 3, Elsevier Ltd, 2014, pp. 115-21, doi:10.1016/j.ccs.2014.07.004.

[4] Baack, Daniel W., et al. “Advertising to Businesses: Does Creativity Matter?” Industrial Marketing Management, vol. 55, Elsevier B.V., 2016, pp. 169-77, doi:10.1016/j.indmarman.2015.10.001.

[5] Veselá, Dagmar, and Katarína Klimová. "Knowledge-Based Economy vs. Creative Economy." Procedia - Social and Behavioral Sciences, vol. 141, Elsevier B.V., 2014, pp. 413-17, doi:10.1016/j.sbspro.2014.05.072.

[6] Greffe, Xavier. "From Culture to Creativity and the Creative Economy: A New Agenda for Cultural Economics." City, Culture and Society, vol. 7, no. 2, Elsevier Ltd, 2014, pp. 7174, doi:10.1016/j.ccs.2015.12.008.

[7] Anoegrajekti, Novi, et al. Etnografi Seni Tradisi Dan Ritual Banyuwangi. Best Publisher, 2019.

[8] Budianta, Melani. “Aspek Lintas Budaya Dalam Wacana Multikutural.” Kajian Wacana Dalam Konteks Multikultural Dan Multidisiplin, edited by Dwi Puspitorini et al., Fakultas Ilmu Pengetahuan Budaya Universitas Indonesia, 2008, pp. 29-42.

[9] Barker, Chris. Cultural Studies Theory and Practice. Sage Publication, 2003.

[10] Spradley, James P. Metode Etnografi. Tiara Wacana Yogya, 1997.

[11] Anoegrajekti, Novi, et al. "Banyuwangi Ethno Carnival as Visualization of Tradition: The Policy of Culture and Tradition Revitalization through Enhancement of Innovation and Locality-Based Creative Industry." Cogent Arts \& Humanities, vol. 5, no. 1, Cogent, 2018, pp. 1-16, doi:10.1080/23311983.2018.1502913.

[12] Zavitz, Amanda Lynn, and Anton L. Allahar. Identity: An International Journal of Theory and Racial Politics and Cultural Identity in Trinidad' $s$ Carnival. no. December 2014, 2009, pp. 37-41, doi:10.1207/S1532706XID0202.

[13] Anoegrajekti, Novi, et al. "Perempuan Seni Tradisi Dan Pengembangan Model Industri Kreatif Berbasis Seni Pertunjukan.” Karsa: Jurnal, vol. 23, 2015, pp. 83-102.

[14] Khairutdinova, D. F. "Boosting Research Skills in Music Students by Means of Staging Folklore Rituals." Procedia - Social and Behavioral Sciences, vol. 191, Elsevier B.V., 2015, pp. 383-86, doi:10.1016/j.sbspro.2015.04.417.

[15] Anoegrajekti, Novi. Optimalisasi Seni Pertunjukan: Kontestasi Negara, Pasar, Dan Agama. Penerbit Ombak, 2016. 